\title{
The Development of Collections in American University Libraries
}

Let no one connected with the promotion of graduate work deceive himself-no single thing is more important in advanced work, that really advances, than the literature of the subject, be it in the sciences, pure and applied, or in the humanities, impure and unapplied. ${ }^{1}$

W ITH THESE wORDS to the Association of American Universities in 1913, Guy Stanton Ford, dean of the graduate school at the University of Minnesota, underscored the close relationship between the quality of graduate education and research and the collections and services of the university library. This relationship is the dominant theme in the development of American university library collections.

Mr. Ford issued his 1913 warning not without justification. At that time graduate education in America had gone through a revolutionary childhood and adolescence. The Ph.D. degree had become an established standard and was well on its way to serving as "a prerequisite for teaching positions of professorial rank in higher education."2 Some 150 institutions were already involved in graduate education at the turn of the century, but very few of them had library facilities that were even close to being adequate. Ford estimated that a collection of approximately 200,000 volumes would be needed as minimal support for a modest Ph.D. program. In 1910, only Harvard, Yale, Berkeley, Chicago, Columbia, Cornell, Michigan, Pennsylvania, and Princeton fell into that category.

\section{Recognition of LibraRy NeEdS}

Reports about inadequacies and frustrations were numerous. The president of Columbia stated: "The university does not need or want books about sources, but the sources themselves." ${ }^{3}$ And from Illinois: "I have had more people whom I have approached to consider positions at the university ... decline ... because of the lack of library facilities than for any other reason." 4

Yet it should be recognized that during the previous forty years a true revolution had taken place in American higher education and in the university libraries. Prior to 1875, "productive scholarship in United States was not associated in any close or direct way with a career in college teaching." 5 America's transformation from a localized economic structure, characterized by artisan technology, into a self-generating national industrial economy accelerated rapidly after the Civil War.

The need for well-trained middle 
management in the increasingly complex industrialized society became apparent, and when the waves of the new European scientific thought and methodology reached America, the foundations for the educational revolution were laid. "The explosion into a vacuum is basically the reason why the United States, starting its scientific revolution much later than Europe, was able to proceed more rapidly to parity and then to outpacing." 6 The system of electives, the seminar method of teaching, and especially the emphasis on research by the university faculty necessitated the establishment and building of library resources as an integral part of the university.

As Holley has indicated in his most useful description of the state of American college libraries around 1876, some of the libraries, notably Harvard, contained very valuable materials. ${ }^{7}$ By and large, however, the collections consisted of gatherings of gifts that never added up to balanced and reliable coverage. The inadequacies of the nation's libraries for research were discussed repeatedly through the first half of the nineteenth century, and the situation had not changed much since 1850 when Jewett actually made a study of the sources cited in a number of important works on a variety of subjects. He concluded that it would have been impossible for the authors to have done their work with the resources available to them in American libraries of that time. $^{8}$

\section{MODELS AND METHODS FOR Developing Collections}

Like the German model Ph.D., the inspiration as well as the experience for development of library collections serving research purposes came from Germany. Up to the eighteenth century the library at Wolfenbüttel had stood as the outstanding scholarly collection. Judiciously built over many generations, substantially with contemporary acquisitions, it contained significant primary and secondary published sources of European scholarship. It was the university library at Göttingen more than any other, however, that provided the link between academic programs and research libraries. Developed over some hundred years, the Göttingen library was considered in the nineteenth century the prime example of what could be achieved through careful planning and continued support. Christian Gottlob Heyne, its celebrated librarian from 1764 to 1812 , summarized his concepts of academic collection development in 1810: "Proper selection rather than mere numbers of books is what makes real worth in a university library. Therefore, the uninterrupted, planned purchase of all important native and foreign publications produced by the development of knowledge is essential for a library with a scholarly plan."9 The quality of the Göttingen library had a strong influence throughout Europe, and it became the standard for the new American universities.

From the very start until today, the use of a model, or a pace setter, has served as a strong force. in the development of university libraries. The Astor Library in New York was undoubtedly the best scholarly collection of its time, and in many ways it set the standard for what materials should be available and how they should be made available. Willard Fiske, who came to Cornell in 1868, after several years at the Astor Library, wrote the president of the Board of Trustees in 1877: "The present situation of the University Library is really deplorable. I refer to the meagerness of its annual appropriation." After further describing in detail the deficiencies, he continued: "In a general way, too, the library is rapidly losing its relative rank among the college libraries of the country, and, within two or three years, will be outstripped by Amherst, Mich- 
igan, Princeton, and other institutions." 10

The newly acquired research-oriented faculty needed a good library, and it was that same faculty that set out to achieve this goal. Actively supported by university presidents such as Gilman (Berkeley and Hopkins), Eliot (Harvard), and White (Cornell), faculty members began to inventory their research needs, and book buying on an unprecedented scale began. The scramble to develop scholarly library collections on short notice brought about an all-out effort to acquire small and large private collections of books and journals built by scholars in a wide range of fields.

That method of acquisition, which began with such collections as the Ebeling (American history, Harvard, 1818) and Neander (church history, Rochester, 1853) before the Civil War, became a major factor in the growth of the then emerging university libraries. In the last quarter of the nineteenth century the outflow of collections from Europe had become such a torrent as to arouse the European scholarly community. In Germany concerned scholars in the field of German language and literature watched such major collections as the Scherer (Western Reserve, 1887), Zarncke (Cornell, 1893), Sauppe (Bryn Mawr, 1894), Hildebrand (Stanford, 1895), and Bechstein (Pennsylvania, 1896) make the one-way trip across the Atlantic. Articles and letters appeared in the press expressing alarm and calling for regulation of this traffic. ${ }^{11}$

Even in fields closer to home, such as Americana, it was the acquisition (usually by gift, but occasionally by purchase) of major private collections, such as the Jared Sparks (Cornell, 1872), John Carter Brown (Brown, 1904), Hubert Howe Bancroft (California, 1905), William L. Clements (Michigan, 1922), Tracy McGregor (Virginia, 1939), and William Robert- son Coe (Yale, 1943), that added the depth to turn the recipient institutions into centers of research on the history of their own country.

In addition to this, the libraries began the effort to identify and systematically acquire the major scholarly sets and journals. These included the significant publications issued by governments, such as parliamentary proceedings, statistical yearbooks, and other official publications; the journals of the European academies many of which dated back into the seventeenth century; the monumental published compilations of historical documents; and major editions and standard literature in all branches of knowledge. Of prime importance were the scholarly and scientific journals reporting significant research output and, of course, the major bibliographical and reference tools. A great number of these books and journals had to be imported from Europe and, from an early date on, the larger libraries established invaluable relationships with agents and booksellers, such as the importing firms of F. W. Christern and Gustav E. Stechert in New York, and overseas agents including Edward G. Allen, B. F. Stevens \& Brown, B. Quaritch, and H. Sotheran in London; F. A. Brockhaus, Gustav Fock, and Otto Harrassowitz in Leipzig; Em. Terquem in Paris; Martinus Nijhoff in The Hague; and Bjork \& Börjesson in Stockholm. Their ready expertise and tradition of conscientious service were major factors in the development of the scholarly collections that were beginning to take shape. By 1897 , some forty libraries were using the services of the German agent Harrassowitz. By the outbreak of World War I that number had risen to $120 .{ }^{12}$ It is not difficult to imagine the effect of this tremendous buying activity on availability and, of course, prices of out-of-print and antiquarian books and journals. 


\section{AMERICAN SCHOLARSHIP AND} Collection Growth

American scholarship developed strongly in the last quarter of the nineteenth century. Fifteen major scientific societies were founded between 1876 and 1905. Among these were the American Chemical Society, the American Mathematical Society, the Modern Language Association, and the Geological Society of America. Increased specialization in scientific and scholarly disciplines changed publishing patterns. The traditional comprehensive treatment of a large subject field, the handbook, was replaced by the scholarly monograph describing one aspect, fact, or figure in a critical fashion. The need to publish reports of research generated the founding of a large number of disciplineoriented journals, many of which were sponsored by the newly founded learned societies. Among the most significant journals that came into being before the turn of the century were the Botanical Gazette (1875), American Historical Review (1895), PMLA (1884), Philosophical Review (1892), Physical Review (1893), and the Journal of Political Economy (1892).

The importance of systematically acquiring currently published material was only slowly recognized. Regular budgets did not really exist, and selection by faculty was in most cases haphazard. Even at Harvard there was some skepticism regarding journals: "The value of them is often in the main temporary, for the more important results are sure to appear sooner or later in the form of monographs. ... We are constantly resisting the pressure to add new ones to our list, yet in spite of ourselves we are spending over a third of our income for periodicals and the publications of learned societies."13

Danton illustrated the quantitative development of collections by calculating the mean annual growth of seven- teen university libraries: ${ }^{14}$

$$
\begin{aligned}
& 1850-1875-1,168 \text { volumes } \\
& 1875-1900-5,135 \text { volumes } \\
& 1900-1920-15,707 \text { volumes }
\end{aligned}
$$

With estimates of the accumulated world book production in 1908 at some $10,000,000$ books and 70,000 journals, it becomes obvious that the share held by even the major American libraries was, to say the least, still rather modest. ${ }^{15} \mathrm{Ex}$ amples have already been cited of user opinion on the quality of the collections. In 1912 Richardson's review of the holdings of European historical sources showed unsatisfactory and very unevenly distributed collections. Of a total of 2,197 titles, Harvard reported having 1,600 (more than there were in all other libraries together), and it was busily acquiring the rest. Yale was adding rapidly too, but only ten other libraries owned 10 percent of the list.16 Even so, a survey of special collections published in the same year indicated pockets of remarkable research strength in a number of university as well as public libraries. ${ }^{17}$

University library collections by 1910 consisted of miscellaneous gifts, books bought in support of classroom teaching, collections of research materials, and special collections. The difference in quality between the libraries was, of course, determined by the mixture of these elements. The universities with the strongest graduate programs had developed the strongest libraries, and that early start has kept almost all of those libraries ranked among the best in the country.

\section{Selection Polictes}

Money has always been the ultimate determining factor in the development of library collections, but planning concepts and selection practices are of almost equal importance. It is not surprising that in the transition period few 
clear goals were set. In the established European tradition the concept of selectivity was held high. Only the "good" books and journals were allowed to become part of the collection. However, there has never been general agreement on what constitutes quality. Europeans emphasized comprehensiveness within the well-bounded realm of their concept of solid research materials. American librarians, on the other hand, from an early date regarded almost all printed material as potentially useful for research and, therefore, favored its gathering and retention.

There has been, and continues to be, running debate on this subject, with the result that in practice no real standards of selection have been applied to the book collections. It has thus been found virtually impossible to design a collection development plan, and a considerable discrepancy has developed between what might potentially be acquired and what actually was brought into the library. The discussion on the desirability of comprehensiveness led to the completely unfounded yet often recurring statement that university libraries can no longer buy all the books they need. In fact, at no time in American library history, including the 1960 s, was it ever the case that the research libraries of the country could satisfy their appetite for books.

An important factor in the shaping of the collections was the almost complete control by the university faculties of book selection and the allocation of book budgets. Because of the varying specialized interests of faculty members, it has always proved difficult to balance a program of buying in support of immediate curricular needs with systematic long-range development of the collections of research tools. Immediate needs have tended to receive the lion's share of attention in those institutions with large numbers of students. Faculty involvement in library affairs has as- sumed an endless variety of formats, but by 1910 most institutions were governed by a library board, which exercised control over the book budget. The available funds were usually allocated to academic departments, and members of the departments were responsible for making purchasing suggestions. The librarian's role was to approve and place the orders, or, at best, to encourage or discourage faculty members.

Only at the largest institutions, notably Harvard and Yale, was the library staff seriously involved in the selection process, and there can be little doubt that this participation contributed substantially to the successful collection development programs at those universities. Yale librarian James T. Babb stated: "At Yale the Librarian has always controlled the book funds and they have not been allocated to the teaching departments. This makes for a more consistent acquisitions policy." 18

\section{Decentraltzation AND Centraltzation}

Another factor that influenced the book selection process was the decentralization of most university library collections. Following the example of the German institutes, the emerging universities of the nineteenth century developed a number of departmental libraries, many of them quite independent from the university library. ${ }^{19}$ At Johns Hopkins and Chicago especially these departmental collections for some time held the most important library resources of the university. Since selection and buying were not coordinated, much duplication occurred, while costly purchases frequently could not be made because the funds were broken up into many small amounts.

The process of centralization has several aspects, including centralized administrative control, centralized processing (acquisitions and cataloging), and the physical merger of collections. A 
campuswide union catalog has usually been one of the early benefits resulting from centralized control, and in most cases this has been followed by at least some degree of centralized ordering and cataloging.

Centralized administrative control has not been achieved easily within the larger and more complex institutions. At Harvard an abortive attempt was made in 1880 by Justin Winsor to centralize acquisition and cataloging, but it failed as a result of the absence of effective administrative control. Harvard's long tradition of separate financing, under the famous principle of "every tub on its own bottom," led to a proliferation of libraries and to the development of each along independent lines. Only with the appointment in 1910 of Archibald Cary Coolidge to the newly created post of director of the university library was a measure of coordination gradually achieved.

At Chicago central control over departmental libraries dates from the appointment of Ernest D. Burton as the first director of libraries in 1910, while at Berkeley a substantial measure of central authority was gained in 1911 by librarian Joseph C. Rowell and associate librarian Harold L. Leupp, with the backing of university president Benjamin Ide Wheeler. On the other hand it was not until 1961 that direction of the libraries of the endowed and state-supported colleges of Cornell was centralized under director of libraries Stephen A. McCarthy.

The persistence of departmental libraries can be credited in part to a widespread acceptance of the idea that the needs of particular groups of students and scholars can best be served by locating specialized library collections in close proximity to the departmental classrooms and laboratories. In part, however, they have developed as a response to the recurrent overcrowding that seems to be the inevitable lot of

\section{growing book collections.}

Conversely, the erection of major library buildings has usually resulted in a consolidation of resources and services. In 1927 Chicago's associate librarian J. C. M. Hanson wrote:
In 1902 the majority of the Faculty evidently favored a further develop- ment of the departmental system to which they had been accustomed since 1892. However, the situation has changed since then. Harvard, Yale, Johns Hopkins, Michigan, Illinois, Minnesota, Cornell, and other univer- sities here and abroad have demon- strated or are demonstrating the fact that the modern central library is in a position, not only to provide most of the advantages of the departmental system, but to improve on them; to fur- nish better service at less cost, better care and supervision of books, better equipment, more and better reference books, and, last but not least, oppor- tunities for that broadening influence which comes from contact with mem- bers of departments other than one's own. ${ }^{20}$

The decision to centralize the control of library operations has marked a turning point in the history of each academic library. It is almost unanimously agreed that administrative and later physical consolidation of library resources and services has increased efficiency in the expenditure of book funds and in processing costs and has greatly improved the utility of the university library as a research instrument.

\section{COOPERATION AND COMPETITION}

From the turn of the century to date, the topic of cooperation between libraries in the development of their collections has been on the minds of university administrators and librarians. Princeton librarian E. C. Richardson made a strong plea in 1899 for a national lending library to alleviate the strugles of the nation's libraries in their effort to "cover the whole ground."21 An 
even stronger identification of the problem of competition was made by Guy Stanton Ford in 1912:

At present, too many universities are buying without due reference to the neighboring collections. Four or five universities within a radius of a hundred to two hundred miles of each other in both eastern and middle western sections are bidding against each other, paying higher and higher prices for rarely used sets of which one or two in a section would by the courtesy of inter-library loans supply all needs. ... I hesitate to name the universities whose libraries-irrespective of their faculties-furnish unrivaled facilities for studying Western history; the list of these, strong in the pamphlet and other source material of the French Revolution, is equally extensive. The next decade will see us bidding and building against each other for South American and Oriental history, politics and literature-not a selected country or period or phase-but all South American and the whole Orient. 22

That was, of course, an administrator's point of view. Some local cooperative arrangements did work successfully. The joint approach by the University of Wisconsin Library and the State Historical Society Library has certainly been effective. The same is true for the coordination of selection between the University of Chicago, the John Crerar, and the Newberry libraries. However, faculty pressure to develop research resources locally prevailed; and, paradoxically, the real strength of most of the research libraries is based on the principle of competition.

\section{Early Twentieth Century ACHIEVEMENTS}

Table 1 at the end of this article illustrates the steady growth of major university library collections during the first four decades of this century, with World War I understandably causing serious interruptions. The most remarkable experience for university libraries during the war was the expression of mutual faith between them and German booksellers. In the full knowledge that the war would come to an end sooner or later, libraries were reserving and holding book funds to pay for the materials missed during the war years. Booksellers, unable to ship materials to library customers overseas, were holding periodical issues for delivery (and payment) later. Libraries which were not so fortunate in their experiences, of course, had a lot of catching up when the war ended.

In general, higher education, graduate education, and especially scientific research grew rapidly. The number of students kept increasing, and the pressure on university libraries was strongly felt. By 1925 the number of institutions seriously involved in graduate education had risen to forty, and many more schools offered master's programs.

A substantial study of the situation in college and university libraries was prepared for the Association of American Universities in 1926. ${ }^{23}$ Eighteen libraries were surveyed, a representative sample of older and newer institutions. It seems useful to pay attention to some of that survey's findings. The format of graduate education, notably the requirements for the Ph.D. degree, had crystallized, but there was a consistent pattern of faculty dissatisfaction with library collections in those institutions where graduate programs were relatively new. Libraries always trailed behind, and considerable frustration was reported from both sides. The more central role that the library was playing in higher education was reinforced by drastic changes in the methods for teaching undergraduates. The textbook was making room for the reading list; and the introduction of honors programs required a much broader choice of book and periodical collections. The division of 
loyalties between support for teaching collections and for research collections characterized collection development in almost all the libraries surveyed.

It is known that in many libraries very large numbers of the additions are duplicates for the reserved readings of undergraduates. It is also known that faculty members frequently mentioned the inadequacy of library resources for their researchers as well as those of their graduate students. . . . The inadequacies are due in some instances to a lack of funds but in others they result from the handling of purchases in a manner that is not designed to make readily possible the securing of the basic materials necessary for research. ${ }^{24}$

The allocation of funds to academic departments was identified as the main stumbling block. Only in a few cases, notably at Illinois, was a large amount of money available to the graduate school for the strengthening of printed resources for research. Once again, the larger, well-established universities experienced greater support for the continued development of the research collections because of faculty efforts. But as libraries grew larger, their ability (and sometimes interest) in developing special research resources diminished. "Evidence was found that in some instances the special collections had been established because of the indifference of the general library to the research and instructional needs of certain phases of university work." 25

The interesting paradox, so characteristic of the large university library, is raised when the report recognized the value of these special collections, of government documents, report literature, archives, etc., but warned sharply that they should not develop without careful consideration of future growth, budget, staffing, and handling. "When ventures of this type are undertaken, the librarian and other administrative offcers of the college and university should be taken into the counsels from the beginning., 26

The more immediate problems of collection development in university libraries in 1926 clustered around an increasing volume of publication, rapidly rising prices, and a decreasing availability of older materials. In addition, attention was directed to "the much larger number of periodicals that are available and that members of the faculty consider essential to successful conduct of their work. Many instances were found in which science departments were obliged to use all of their allotment for library purposes to purchase the periodical literature that was regarded as necessary for the work of the department." 27

Prices for a list of 633 periodicals received at Cornell increased 181.9 percent between 1910 and $1925 .{ }^{28}$ The continuous buying of backsets of periodicals virtually depleted the market in Europe as well as in the U.S. ${ }^{29}$ What did come on the market consequently became more and more expensive. Despite shortcomings and frustrations, significant additions were made to the nation's research libraries. An ALA survey of 1927 shows approximately 4,500 special collections. When compared with earlier surveys, there are represented a much wider variety of subject fields and a greater geographical spread. ${ }^{30}$

\section{The Depression Years}

William Warner Bishop wrote: "To anyone attempting review of the history of American libraries as a group it is apparent that their growth has been almost entirely individual, unplanned with reference to any other library or group of libraries." ${ }^{31}$ This observation is certainly valid for the development of the collections in university libraries during the years of economic depression in the 1930s.

State by state, institution by institution, the experience was different. More 
and more students came to the universities, more and more Ph.D.s were awarded. In most libraries acquisitions rates increased, but not enough to keep up with rising demands. "Extended and improved as they have been, the university libraries cannot keep pace with the demands made upon them by the ever swelling miscellaneous student body." 32 In addition, growth of research and teaching in the social sciences put new demands on libraries. The increased published output of primary data by government agencies required special attention. Virtually all the major libraries showed a decline in growth rate during the period between 1930 and 1933, but soon afterward the number of volumes acquired increased again. ${ }^{33}$

In the last decade before World War II the collections in the five oldest university libraries grew an average of 42.3 percent; the five youngest increased by 93.6 percent, a clear indication of the strong pressure on those libraries to provide basic resources for the growing graduate programs. Several institutions suffered severely during that period. Cornell and Johns Hopkins, of the older libraries, were forced to reduce their acquisitions rate. The rank order in size, deceptive as that may be, changed dramatically as a result of uneven funding. Figures 1 and 2 illustrate some of these differences for a selected group of institutions.

The application of microfilm technology had far-reaching consequences for research libraries during this period. It opened up research resources not previously available in individual institutions or, for that matter, in the country. Now manuscript materials and early printed as well as ephemeral material could readily be added to collections; and although not all librarians and professors were easily convinced, the active research community jumped at the opportunity. "There is very little question that photographic copying, whether by photostat for short articles or by film for longer ones and for books, is going to be the solution to many of the difficulties involved in building up competent research materials in our libraries." 34

\section{WORLD WAR II}

The independent and competitive development of university library collections has been criticized repeatedly for its waste of financial resources. ${ }^{35}$ Another unfortunate dimension of this lack of national planning became apparent at the outbreak of World War II. The stepped-up research efforts, especially in war technology, revealed that a substantial number of important scientific books and journals from abroad had never been acquired by any of America's libraries. Renewed acquisitions efforts got under way, but when the Netherlands was occupied by Germany in May 1940, the supply stopped.

"Until the American entry into the War, many American libraries, working through a Joint Committee on Importations, which was particularly effective in dealing with British censorship, managed to obtain reasonably good coverage of European and Japanese journals." 36 Sometimes the British would hold up shipments for considerable periods. In 1941 the British released, only after intense negotiation, $\$ 250,000$ worth of materials from Europe destined for nongovernmental libraries. The Library of Congress was authorized to purchase these materials for distribution, marking the first of a long series of actions by that agency in the procurement of foreign materials for research libraries.

Efforts to supply the various war agencies with needed books and journals were quite successful, through the work of the Interdepartmental Committee for the Acquisition of Foreign Publications. ${ }^{37}$ Some of the material thus acquired reached university libraries in the form of photocopy or microfilm. 


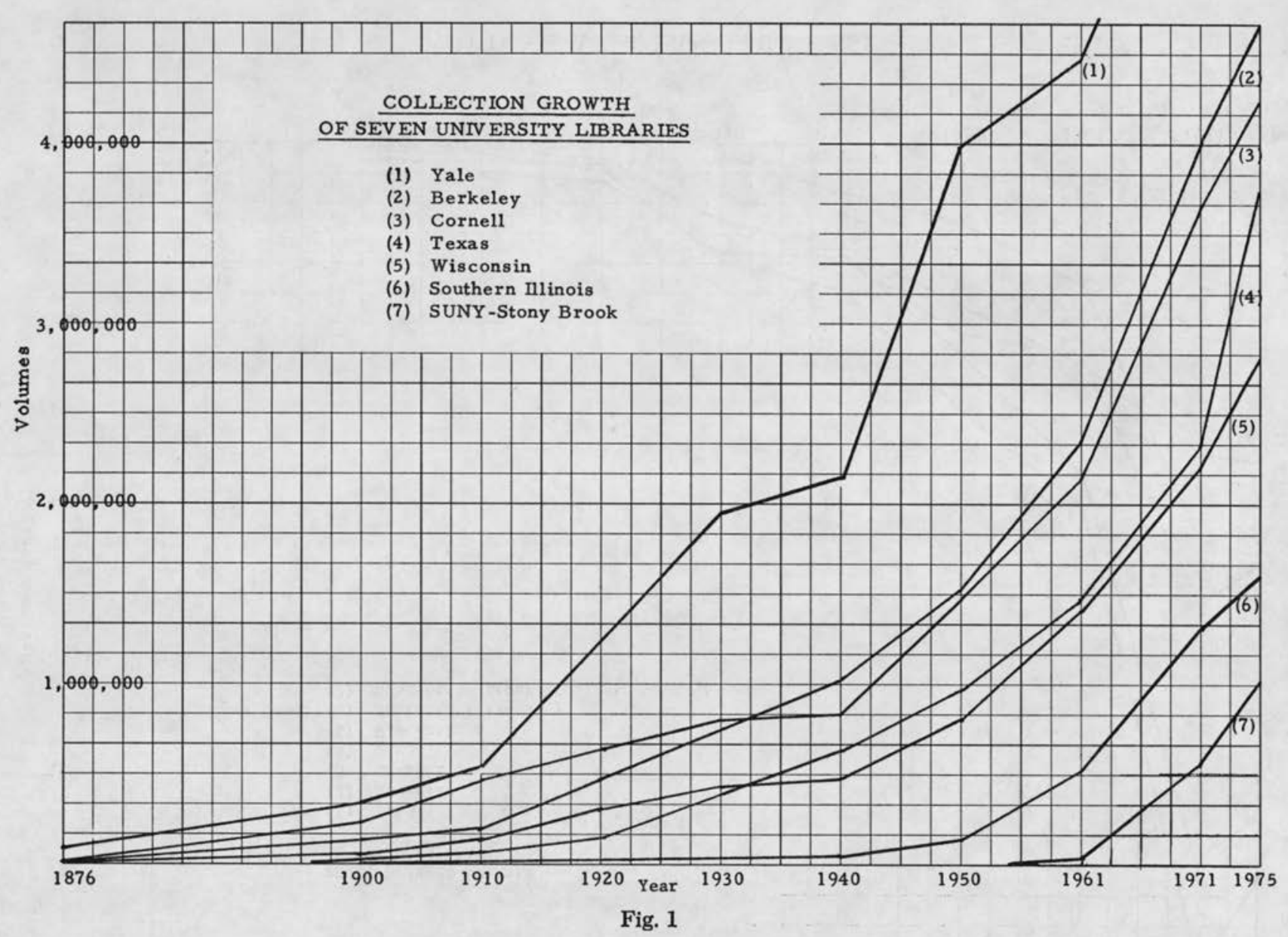

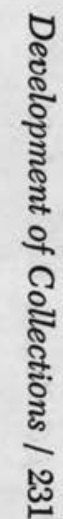
Source: See Table 1.

Collection Growth of Seven University Libraries 


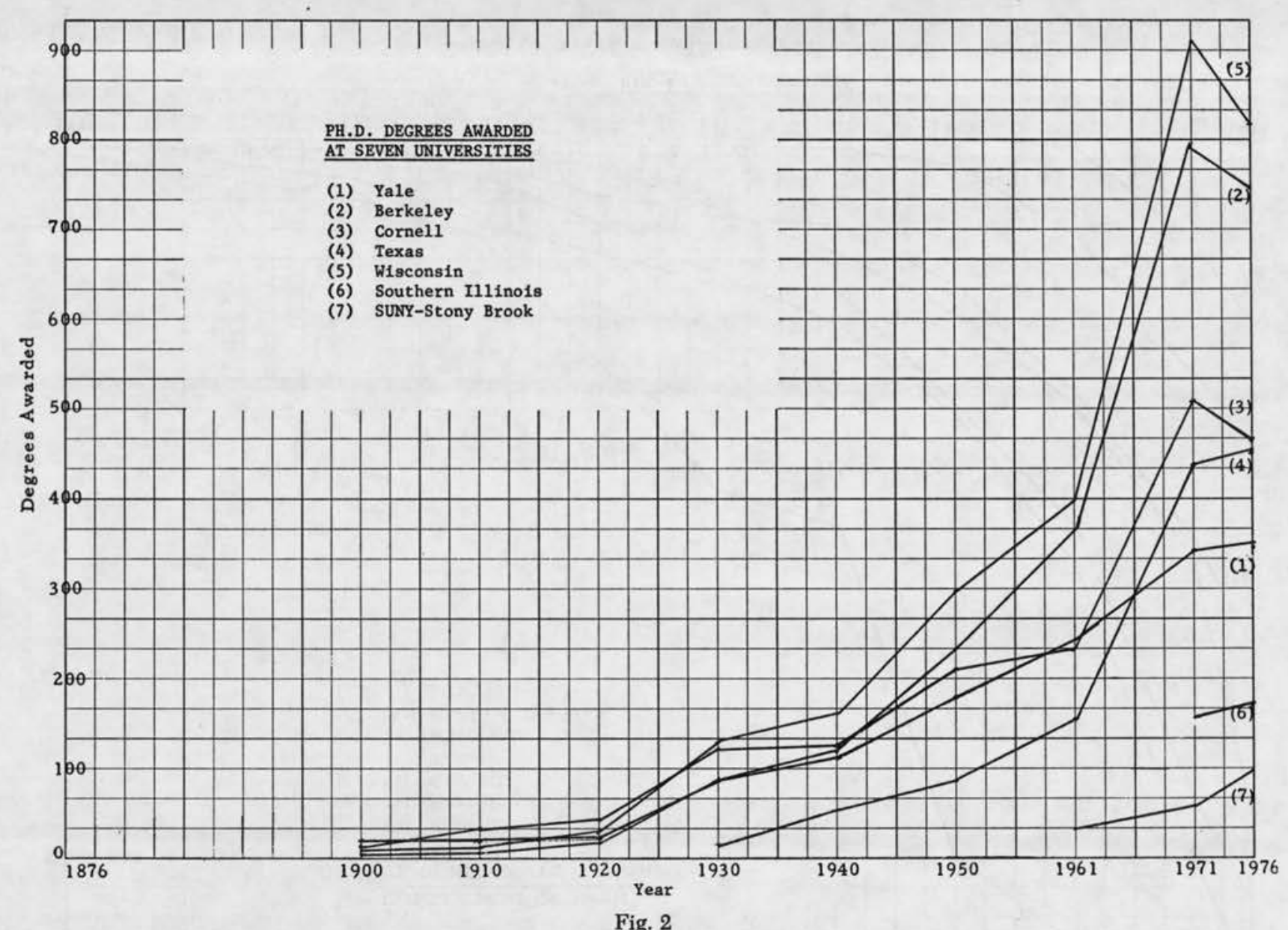

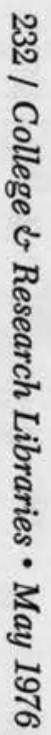

Source: See Table 1.

Ph.D. Degrees Awarded at Seven Universities 
But researchers needed not only wartime publications; there was a sharp rise in demand for backsets of significant German and other European scientific publications. With the supply lines completely cut off, various reprint programs were started in 1943 under the auspices of the Alien Property Custodian. These programs eventually provided current as well as back issues of 116 periodical titles and some 700 books from enemy countries. $^{38}$ Virtually all titles were in the sciences. The same program propelled several new companies into the mainstream of library suppliers. Among these were Kraus Reprint, Johnson Reprint, and University Microfilms.

In the same year, 1943, the Library of Congress was permitted to send a representative behind the troops in Africa and Italy and later in France to procure whatever materials were available. This, of course, did not help university libraries very much. The model, however, led to the Cooperative Acquisitions Project in 1945. The Library of Congress, with appropriate help from other government agencies, acted as European agent in purchasing wartime materials in many different countries. In addition, confiscated Nazi collections, printed war propaganda, and military "loot" were made available. A carefully worked out scheme of subject responsibilities and regional priorities allowed some $130 \mathrm{li}$ braries to receive wartime imprints at only nominal cost. In total, over two million pieces were distributed, with the largest part being received by the $\mathrm{Li}$ brary of Congress, New York Public Library, Harvard, Yale, Columbia, Illinois, California, and Chicago. ${ }^{39}$

An especially successful accomplishment of the project was the negotiated release from Russian authorities of large quantities of serial issues held for American libraries by Leipzig publishers and booksellers. "This remarkable accomplishment, together with the general work of the project, made the World
War II period one of the strongest, rather than one of the weakest periods in the holdings of American research libraries." 40

\section{The Postwar Period}

There is a more than adequate and easily accessible literature describing the causes and effects, the facts and figures of the spectacular rise in American higher education after World War II and likewise of the apparent decline during the past few years. In many ways the table at the end of this article demonstrates these fluctuations. What is of interest here and has not as yet been so well covered is an analysis of the acquisitions of university libraries during the last quarter century. Such an analysis, however, is difficult because there is no satisfactory descriptive model for university library collections and their development.

Since the 1930s greater emphasis has been placed on current coverage of the scholarly book and journal production, as well as on the acquisition of official and semiofficial publications. Strong faculty involvement in the selection over a long period of years made the collections of most of the libraries clearly reflect the strengths as well as the weaknesses of American scholarship.

Prior to World War II this tradition was very much based on the Western European and Anglo-American experience. Other than the traditional classical studies of the ancient cultures in the Near and Far East, the rest of the world was largely viewed from the standpoint of European expansion. As a result, university libraries were almost wholly dominated by Western publications. The lack of information on nonWestern areas became acute during World War II, when America's military and political efforts suddenly developed on a global scale. The demand for materials with current economic, geographic, linguistic, political, anthropological, 
and sociological information on varied cultures and countries in Africa and Asia rose rapidly.

\section{Area Study Programs}

American power around the world generated demands for trained personnel in the postwar era, and the universities responded with vigor to the challenge. Area programs were organized at all major universities. With substantial help from the Rockefeller, Carnegie, Ford, and lately Mellon foundations, as well as from the government through the National Defense Education Act, professors and librarians began building collections in new fields. Chinese and Japanese books and journals were rapidly acquired, with emphasis on vernacular language materials. The cold war and especially Sputnik in 1957 stimulated the development of Russian language collections. Latin American interest increased; South Asia, South East Asia, Africa, the Middle East, and South Eastern Europe all required substantial attention. There were numerous selection, acquisition, and cataloging problems to overcome, and large investments in human resources became necessary to operate these library programs.

A very substantial part of the growth of the large research libraries may be attributed to area program-related acquisitions. The need for comprehensive coverage was obvious; the resources in countries such as China and Russia were not accessible to American scholars. In many other non-Western countries, no library programs for collecting and preserving printed materials existed at all. Within a very short period of time, America's universities developed library resources of unique depth and scope. Like earlier library developments, however, independence and competition were essential motivators. Only recently have the funding agencies attempted to concentrate their support on the most successful programs.
Throughout the postwar period the Library of Congress has shared its experience and expertise with other libraries. Using imaginative legislation, the Library of Congress started in 1962 a cooperative acquisitions program for India and Egypt under Public Law $480 .{ }^{41}$ At various times the program operated in Israel, Pakistan, Ceylon, Indonesia, Poland, and Yugoslavia, depending on available funds. Some of these publicly funded programs have been followed by joint acquisitions programs in which individual libraries pay for their share. Some forty university libraries share in one or more of these programs.

Various other cooperative acquisitions programs have been or are effective. The commercially operated Latin American program was terminated in $1974,{ }^{42}$ but the Center for Chinese Research Materials, operated by the Association of Research Libraries, continues to be most effective in reproducing and distributing scarce materials. Efforts to coordinate the development of the various area programs nationally by "dividing up the world" among major universities have, however, failed. Only the natural selection through survival seems effective in eliminating weaker programs. Fears are increasingly being expressed that the leading academic libraries will not be able to maintain the strength of their unique resources, not only because of diminished outside support but because of fiscal problems within universities themselves. ${ }^{43}$ As of this time, no solution is in sight.

\section{European Materials}

Surprisingly enough, interest in Europe has not developed in the same way. Traditional studies in history, literature, and the arts have continued to grow vigorously, but until recently there has been no substantial organized interest in the study of modern European societies. As a result, academic libraries 
have not made as much of an effort to acquire the sociological, political, and economic literature originating outside the traditional publishing channels. Although a serious survey is long overdue, there is every indication that a large part of this "grey literature" has not been acquired systematically by any of this country's research libraries, with the possible exception of the Hoover Institution at Stanford University.

The frustrating experience with European publications during World War II led to the much heralded beginning of the Farmington Plan in 1948. Designed with severe limitations as to coverage, very complex distribution of subject assignments among libraries, and the absence of an adequate control mechanism, the Farmington Plan in reality served little more than a symbolic purpose. ${ }^{44}$

Soon after the war was over, university libraries reestablished relationships with European dealers, and before long, large selections of "trade published" books and journals were being acquired. Shortly after 1960 many of the larger libraries established blanket order programs with European agents. Coverage of these programs has been refined and broadened since the Library of Congress set up acquisitions offices in 1965 under the National Program for Acquisitions and Cataloging. During the past few years Europe has once again emerged as an academic "problem" area, and without doubt we shall soon see renewed attention given to related library acquisitions.

Ironically, language study requirements in American universities were steadily lowered during the rise of American political and military power abroad and the dominance of American scholarship in modern social science disciplines. With the apparent decline of that influence in the late 1960 s, there has been a visible increase in the quan- tity of research publication in other languages.

\section{Publication Rates and \\ Higher Education}

In many of the large university libraries more than 60 percent of acquisitions have come from abroad. ${ }^{45}$ World book production rose from an estimated 184,000 volumes in $1937^{46}$ to 561,000 in 1972.47 U.S. book production also tripled: 10,640 in 1939 and 30,000 in 1974. ${ }^{48}$ The output of American university presses, to a certain extent an indicator of scholarly book production, rose from 727 titles in 1948 to 1,846 in $1974.4^{49}$ But clearly, the growth of the collections in university libraries has gone well beyond the increase in publication of new titles.

The dramatic rise in the number of students during the past twenty-five years has required the provision of large numbers of multiple copies, as well as numerous other purchases in support of the teaching programs. Recognizing the very different needs of graduate students and research faculty on the one hand and undergraduates on the other, many universities followed Harvard's example in establishing separate undergraduate libraries. The experience at other institutions, such as Michigan and Cornell, brought about a unique collaborative effort of faculty members and librarians in conceptualizing the "ideal" college collection. This effort led ultimately to publication of the selection guide for three new campuses of the University of California. ${ }^{50}$ The publication of this list has had a notable impact on the development of academic library collections, and it was quickly raised to "Bible" status.

Meanwhile, the spread of the number of universities offering Ph.D. degrees created a market large enough for commercial republication of large numbers of scholarly and scientific journals, as well as of individual books. Library 
budget increases, because of intense faculty pressure to make up for past deficiencies or to develop collections in fields not previously touched, resulted in a visible expansion of the market. A relatively small group of enterprising publishers and booksellers, domestic as well as foreign, jumped at this opportunity, and their offerings quickly emphasized the apparent shortcomings of the collections. This spiral movement of demand and supply was reinforced by the large sums of money made available to libraries under the Higher Education Act of 1965.

Not only had a good number of the standard sources become available again, but the availability of previously inaccessible materials, such as newspapers, historical archives, and complete collections of early American and early English books, greatly improved the research resources of scholarly libraries. Much of this expansion was through publication in microform. The same format of publishing assisted in solving problems of space and physical deterioration of printed books and journals.

\section{New Selection Practices}

Recognizing the need for coordinated and systematic development of the collections, enlightened faculties at many universities increasingly relied on librarians to guide the selection process. A generation of uniquely capable bibliographers such as Donald Wing at Yale, Felix Reichmann at Cornell, Rudolf Hirsch at Pennsylvania, and Elmer Grieder at Stanford made their mark. By the 1960s the scope and size of the selection process had grown well beyond the capabilities of part-time faculty selectors, and one by one each of the larger libraries appointed an in-house book selection staff. The subject bibliographer arrived on the scene, combining selection responsibilities with library-faculty liaison. Although individ- ual faculty members have continued to exert influence in development of collections, more and more the daily selection tasks were transferred to the library.

The high acquisition rate of currently published materials led to novel selection techniques. The imaginative and enterprising bookseller Richard Abel expanded the old concept of the approval plan to a comprehensive level in various subject categories. As other booksellers followed suit, many university libraries were induced to sign up with one plan or another. The effectiveness of such approval plans was highest in libraries that utilized the service as a means of identifying appropriate books to review for selection. When such screening had to be applied in the face of decreasing purchasing power in the 1970 s, problems arose, and with the financial demise of the Richard Abel Company in 1974 the popularity of approval plans dropped significantly. Nevertheless, new standards of service by American booksellers to academic libraries had been set.

Before World War II the publishing of scholarly and scientific periodicals was largely in the hands of learned societies or other not-for-profit agencies. The explosion in the production of scientific information brought a proliferation of new journals. The ready market attracted commercial publishers into the field, and the share of the book funds allocated for periodical subscriptions by the university libraries began to rise rapidly during the latter 1960s. In recent years that share has increased even more dramatically, as the result of inflation and shifts in international currency exchange rates. At present, balanced collection development plans are being seriously disrupted, and libraries have been forced either to sharply reduce their subscription lists or to decrease their book purchases disproportionately. ${ }^{51}$ 


\section{Cooperative Programs}

We have already alluded to the failure of attempts at establishing working agreements on divided collection development responsibilities among the major research libraries. Several cooperative programs have been successful, however. Under the auspices of the Association of Research Libraries, American doctoral dissertations have been made widely accessible through an extensive program of microfilming by University Microfilms and the provision of comprehensive bibliographical tools. Several collecting programs at the Center for Research Libraries, notably those involving foreign doctoral dissertations, foreign newspapers, state documents, and large microform projects, have not only allowed individual libraries selectively to reduce their coverage but, more importantly, have provided a reliable national resource.

\section{Special Resources}

Major research resources in the form of various special collections of rare books, manuscripts, and archives have been developed during the past twentyfive years. Harvard, Yale, and Indiana, among others, have built special facilities, thereby increasing service as well as visibility. Endowments, alumni, and "friends" are the main sources of funding for these activities in most cases. Many of the newer university libraries have successfully developed collections of contemporary authors; other libraries have added archival collections of social, political, or historical significance. The most spectacular acquisitions program has been the building of the Humanities Research Center at the University of Texas. Its creation proved that, even in a market of limited supply, the combination of determination and a liberal supply of funds can still lead to the development of truly great research collections.

\section{ConCLUSION}

Good scholars need good libraries, and good libraries attract good scholars. This interaction is the dominant theme in the story of American university libraries. With very few exceptions the prominent graduate programs at the turn of the century created the outstanding library collections of that time. Twenty-five years later, a review of perceived quality in graduate education closely correlated with the numerical ranking of the library collections. ${ }^{52}$ (This correlation, it should be noted, applies principally to studies in the humanities and social sciences, and the academic prominence at that time of institutions such as the Massachusetts Institute of Technology and the California Institute of Technology does not correlate strongly with the size of their collections.)

A more sophisticated evaluation of graduate schools took place in $1965 .{ }^{53}$ Once again it was found the top twentyfive humanities and social science programs are located at the universities that have the largest book collections, although the relative ranking in individual subject fields does not necessarily match the overall strength of the respective libraries. The notable exceptions in this listing are the Massachusetts Institute of Technology and the Graduate Center of the City University of New York, both of which are located in immediate proximity to excellent research library collections.

The collections of American university libraries have been built with vision, ambition, knowledge, dedication, and large amounts of money. The influence of pacesetters has been great, yet each university library reflects very much the particular academic history of its institution and especially the influence of a relatively small number of scholars and librarians. On balance, it has always been the scholar who provided the impetus; the librarian has made it possible. 
TABLE 1

Library Holdings (in Thousands of Volumes) of and Ph.D. Degrees

Awarded by Major American Public and Private Universities, 1876-1975.

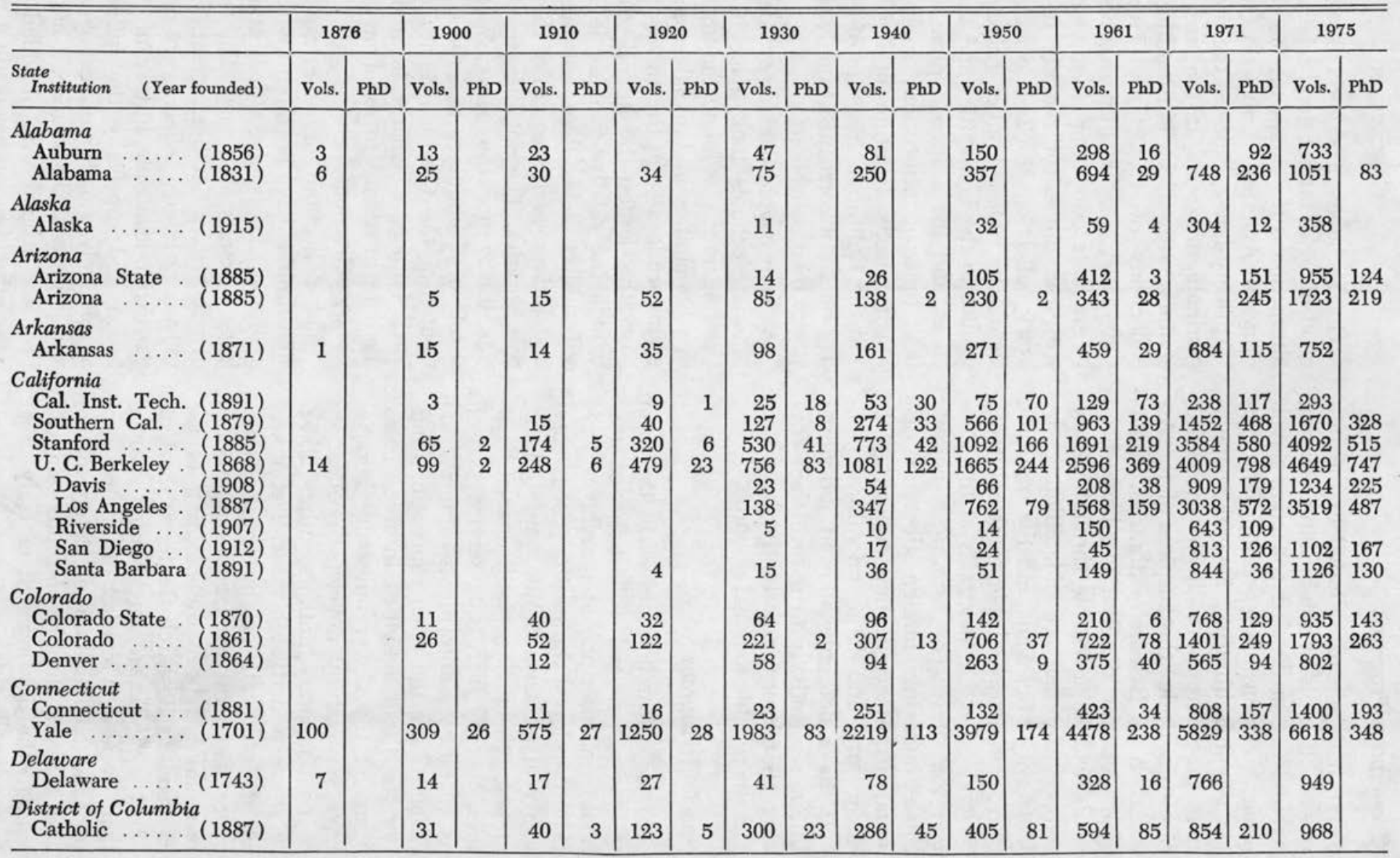




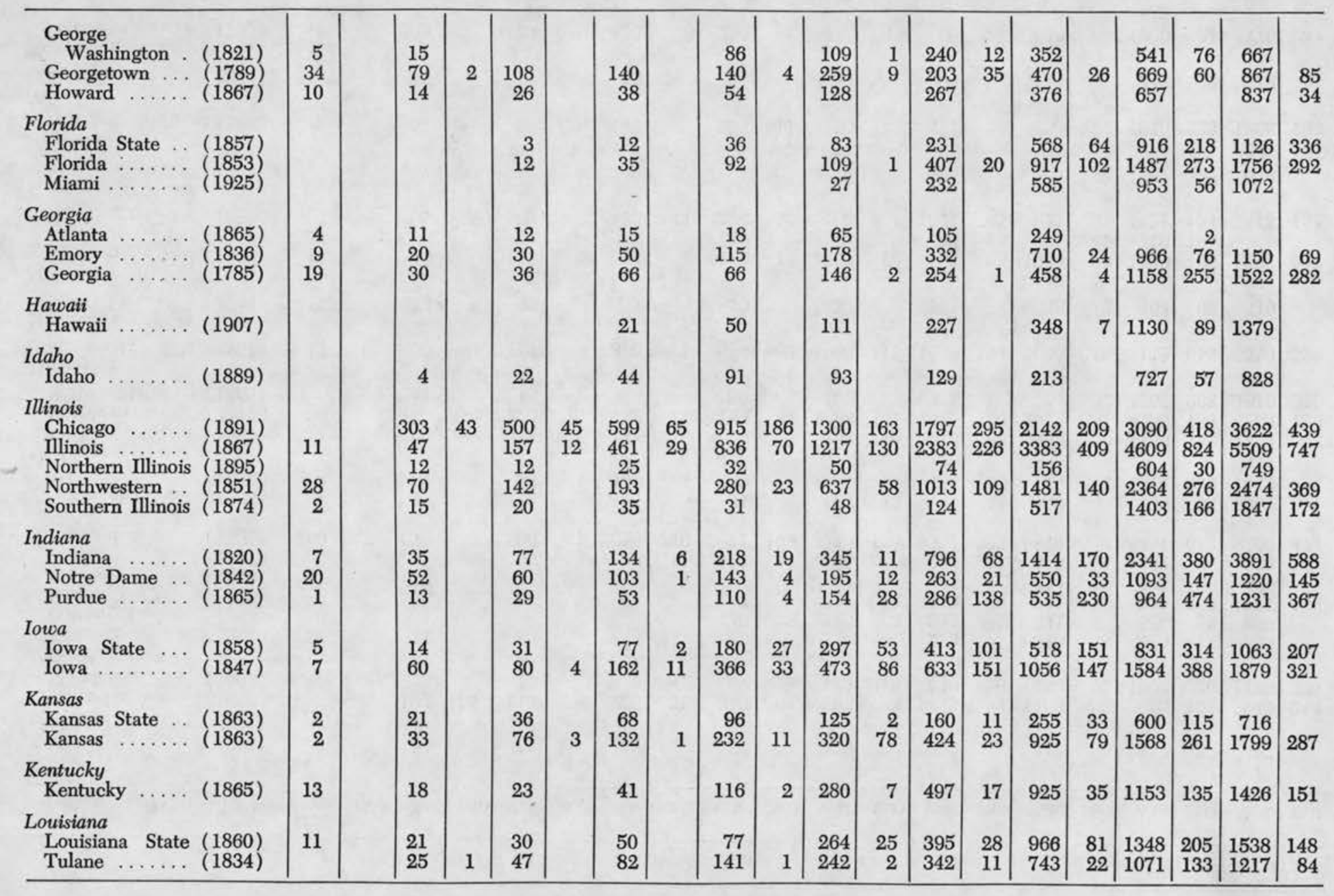




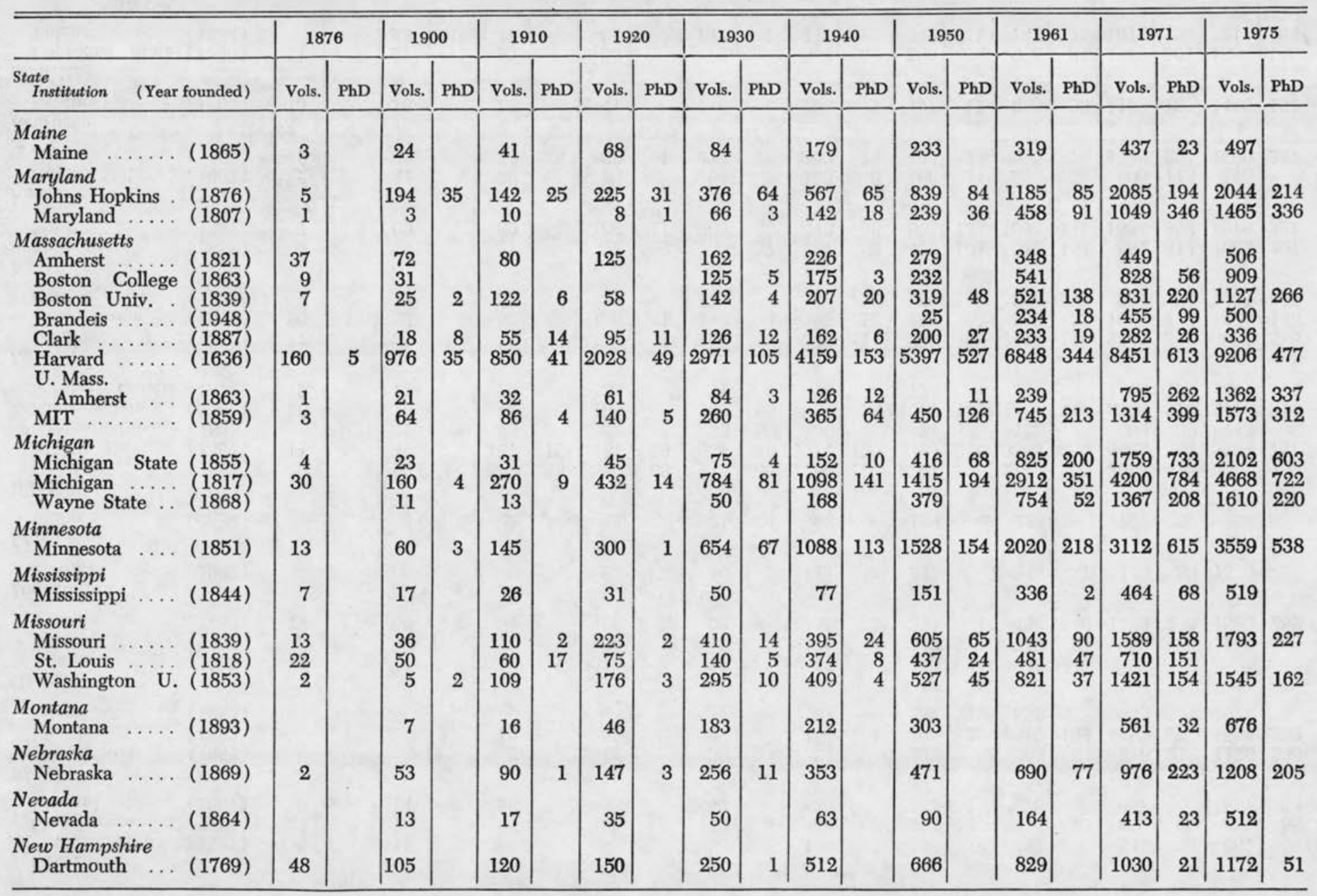




\begin{tabular}{|c|c|c|c|c|c|c|c|c|c|c|c|c|c|c|c|c|c|c|c|}
\hline $\begin{array}{l}\text { New Hampshire (1866) } \\
\text { New Jersey }\end{array}$ & & 6 & & 26 & & 40 & & 66 & & 106 & & 170 & & 295 & 9 & 560 & 29 & 698 & \\
\hline Princeton ..... (1746) & 46 & 144 & 3 & 270 & 9 & 444 & & 643 & 31 & 959 & 43 & 1166 & 80 & 1689 & 140 & 2314 & 255 & 2715 & 251 \\
\hline $\begin{array}{l}\text { Rutgers ...... (1766) } \\
\text { New Mexico }\end{array}$ & 11 & 46 & & 61 & & 106 & 1 & 239 & 5 & 342 & 12 & 573 & 49 & 961 & 81 & 1164 & 182 & 1839 & 258 \\
\hline $\begin{array}{l}\text { New Mexico . . (1889) } \\
\text { New York }\end{array}$ & & 4 & & 8 & & 13 & & 34 & & 80 & & 184 & 5 & 326 & 23 & 720 & 129 & 886 & \\
\hline City College .. (1847) & 19 & 33 & & 39 & & 71 & & 100 & & 245 & & 370 & & 522 & & & 112 & 863 & \\
\hline Columbia $\ldots$. (1754) & 17 & 345 & 21 & 448 & 44 & 747 & 69 & 1222 & 184 & 1715 & 198 & 1897 & 456 & 2939 & 329 & 4241 & 505 & 4661 & 521 \\
\hline $\begin{array}{lll}\text { Cornell } & \ldots \ldots & (1865) \\
\text { Fordham } & \ldots \ldots & (1841)\end{array}$ & 39 & 268 & 19 & $\begin{array}{r}383 \\
50\end{array}$ & 35 & $\begin{array}{l}630 \\
100\end{array}$ & $\begin{array}{r}45 \\
7\end{array}$ & $\begin{array}{l}810 \\
110\end{array}$ & $\begin{array}{r}129 \\
54\end{array}$ & $\begin{array}{l}844 \\
198\end{array}$ & $\begin{array}{r}131 \\
23\end{array}$ & $\begin{array}{r}1463 \\
260\end{array}$ & $\begin{array}{r}210 \\
43\end{array}$ & $\begin{array}{r}2198 \\
401\end{array}$ & $\begin{array}{r}239 \\
77\end{array}$ & $\begin{array}{r}3779 \\
997\end{array}$ & 508 & 4272 & 460 \\
\hline $\begin{array}{l}\text { NYU } \\
\text { SUNY }\end{array}$ & 4 & 54 & 7 & 100 & 10 & 153 & 6 & 319 & 46 & 592 & 125 & 888 & $\begin{array}{r}43 \\
179\end{array}$ & $\begin{array}{r}401 \\
1121\end{array}$ & $\begin{array}{r}77 \\
307\end{array}$ & $\begin{array}{r}927 \\
2111\end{array}$ & $\begin{array}{r}94 \\
567\end{array}$ & 2456 & 488 \\
\hline Albany .... (1844) & & & & & & 2 & & 15 & & 30 & & 46 & & 65 & & 611 & 50 & 1007 & 110 \\
\hline $\begin{array}{l}\text { Buffalo ..... (1846) } \\
\text { Stony Brook }\end{array}$ & & & & & & 29 & & 62 & & 161 & & 195 & & $\begin{array}{r}374 \\
35\end{array}$ & 29 & $\begin{array}{r}1575 \\
586\end{array}$ & $\begin{array}{r}245 \\
55\end{array}$ & $\begin{array}{r}1523 \\
956\end{array}$ & $\begin{array}{r}241 \\
98\end{array}$ \\
\hline Syracuse ..... (1870) & 9 & 64 & & 78 & 1 & 109 & 2 & 195 & 2 & 322 & 3 & 348 & 36 & 559 & 94 & 1548 & 231 & 1541 & 216 \\
\hline Rochester ... (1850) & 12 & 40 & & 52 & & 83 & & 190 & 2 & 360 & 25 & 514 & 36 & 721 & 61 & 1179 & 198 & 1402 & 200 \\
\hline $\begin{array}{l}\text { North Carolina } \\
\text { Duke ........ (1838) }\end{array}$ & 12 & 16 & & 40 & & & & 192 & 8 & 600 & 23 & 994 & 46 & & & & & & \\
\hline N. C. State ... (1891) & 12 & 4 & & 8 & & 10 & & 30 & 0 & 55 & 23 & $\begin{array}{l}994 \\
108\end{array}$ & 46 & $\begin{array}{r}1493 \\
226\end{array}$ & $\begin{array}{l}82 \\
48\end{array}$ & $\begin{array}{r}2231 \\
550\end{array}$ & $\begin{array}{l}220 \\
203\end{array}$ & $\begin{array}{r}2622 \\
692\end{array}$ & 155 \\
\hline North Carolina (1789) & 17 & 43 & & 58 & & 93 & & 223 & 27 & 386 & 34 & 557 & 100 & 1077 & 96 & 1819 & 245 & 2125 & 332 \\
\hline $\begin{array}{l}\text { North Dakota } \\
\quad \text { North Dakota . (1883) }\end{array}$ & & 10 & & 35 & & 58 & & 98 & & 89 & 2 & 165 & 2 & 226 & 10 & & 85 & 341 & \\
\hline $\begin{array}{l}\text { Ohio } \\
\text { Case Western }\end{array}$ & & & & & & & & & & & & & & & & & & & \\
\hline $\begin{array}{r}\text { Reserve } \\
\text { Cincinnati }\end{array}$ & 11 & $\begin{array}{l}36 \\
32\end{array}$ & & $\begin{array}{r}90 \\
118\end{array}$ & & 138 & & 350 & 5 & 554 & 25 & 644 & 33 & 758 & 51 & 1175 & 326 & 1558 & 227 \\
\hline $\begin{array}{l}\text { Cincinnati } \ldots .(1819) \\
\text { Kent State .... }\end{array}$ & 1 & 32 & & 118 & 1 & 125 & 2 & 256 & 14 & $\begin{array}{r}491 \\
76\end{array}$ & 27 & $\begin{array}{l}649 \\
106\end{array}$ & 20 & $\begin{array}{l}813 \\
204\end{array}$ & 5 & $\begin{array}{r}1156 \\
648\end{array}$ & 48 & $\begin{array}{l}1553 \\
1066\end{array}$ & $\begin{array}{l}147 \\
103\end{array}$ \\
\hline Oberlin ...... (1832) & 15 & 59 & & 98 & & 204 & & 323 & & 404 & & 486 & & 552 & & 695 & & & 100 \\
\hline Ohio State .... (1870) & 1 & 45 & & 95 & & 215 & & 359 & 68 & 552 & 97 & 863 & 229 & 1447 & 260 & 2539 & 676 & 3033 & 649 \\
\hline Ohio Univ. ... (1804) & 6 & 17 & & 30 & & 52 & 2 & 75 & & 127 & & 197 & & 312 & 5 & 460 & 108 & 652 & \\
\hline $\begin{array}{l}\text { Oklahoma } \\
\text { Oklahoma State }(1890)\end{array}$ & & & & 14 & & 25 & & 58 & & 139 & 5 & 275 & 15 & 619 & 53 & 1006 & 217 & 1141 & 213 \\
\hline $\begin{array}{l}\text { Oklahoma } \ldots . .(1890) \\
\text { Oregon }\end{array}$ & & 8 & & 16 & & 32 & & 130 & & 217 & & 333 & 15 & 782 & 49 & 1158 & 220 & 1285 & 249 \\
\hline Oregon State .. (1868) & & 3 & & 8 & & 41 & & 93 & & 172 & 4 & 252 & 20 & 396 & 52 & 643 & 208 & 736 & \\
\hline Oregon $\ldots \ldots$ (1872) & & 11 & & 30 & & 94 & & 233 & 2 & 307 & 2 & 451 & 12 & 822 & 49 & 1104 & 349 & 1266 & 250 \\
\hline $\begin{array}{l}\text { Pennsylvania } \\
\text { Lehigh ....... (1865) }\end{array}$ & 2 & 115 & & 125 & & 100 & & 190 & & 245 & & 310 & 19 & 391 & 25 & 549 & 109 & 612 & \\
\hline
\end{tabular}




\begin{tabular}{|c|c|c|c|c|c|c|c|c|c|c|c|c|c|c|c|c|c|c|c|c|}
\hline \multirow[b]{2}{*}{$\begin{array}{l}\text { State } \\
\text { Institution (Year founded) }\end{array}$} & \multicolumn{2}{|c|}{1876} & \multicolumn{2}{|c|}{1900} & \multicolumn{2}{|c|}{1910} & \multicolumn{2}{|c|}{1920} & \multicolumn{2}{|c|}{1930} & \multicolumn{2}{|c|}{1940} & \multicolumn{2}{|c|}{1950} & \multicolumn{2}{|c|}{1961} & \multicolumn{2}{|c|}{1971} & \multicolumn{2}{|c|}{1975} \\
\hline & Vols. & $\mathrm{PhD}$ & Vols. & $\mathrm{PhD}$ & Vols. & $\mathrm{PhD}$ & Vols. & $\mathrm{PhD}$ & Vols. & $\mathrm{PhD}$ & Vols. & $\mathrm{PhD}$ & Vols. & $\mathrm{PhD}$ & Vols. & $\mathrm{PhD}$ & Vols. | & $\mathrm{PhD}$ & Vols. & $\mathrm{PhD}$ \\
\hline Penn. State ... (1855) & 3 & & 16 & & 40 & & 75 & & 120 & 3 & 207 & 40 & 323 & 69 & 620 & 175 & 1165 & 601 & 1825 & 340 \\
\hline Pennsylvania .. (1740) & 20 & 7 & 260 & 15 & 293 & 35 & 503 & 21 & 712 & 90 & 934 & 71 & 1194 & 124 & 1703 & 157 & 2329 & 362 & 640 & 326 \\
\hline Pittsburgh .... (1787) & & & 15 & & 15 & 2 & 24 & 3 & 145 & 22 & 191 & 43 & 578 & 80 & 977 & 112 & 1456 & 57 & 1972 & 412 \\
\hline Temple ...... (1884) & & & & & & & & & 41 & & 149 & 8 & 322 & 14 & 527 & 34 & 1029 & 147 & 1247 & 102 \\
\hline $\begin{array}{l}\text { Puerto Rico } \\
\text { Puerto Rico ... (1900) }\end{array}$ & & & & & & & 8 & & 25 & & 73 & & 123 & & 538 & & 879 & & & \\
\hline Rhode Island & & & & & & & & & & & & & & & & & & & & \\
\hline $\begin{array}{l}\text { Brown } \\
\text { Rhode Island } .(1764)\end{array}$ & 46 & & 135 & 3 & $\begin{array}{r}186 \\
17\end{array}$ & 5 & $\begin{array}{r}270 \\
22\end{array}$ & 3 & $\begin{array}{r}403 \\
25\end{array}$ & 11 & $\begin{array}{r}573 \\
60\end{array}$ & 19 & $\begin{array}{l}735 \\
105\end{array}$ & 35 & $\begin{array}{r}1059 \\
194\end{array}$ & 3 & $\begin{array}{r}1390 \\
437\end{array}$ & $\begin{array}{r}156 \\
45\end{array}$ & $\begin{array}{r}1536 \\
584\end{array}$ & 145 \\
\hline $\begin{array}{l}\text { South Carolina } \\
\text { South Carolina (1801) }\end{array}$ & 30 & 2 & & & 43 & & 65 & & 110 & & 156 & & 212 & & 496 & 7 & 934 & 80 & 1372 & 106 \\
\hline $\begin{array}{l}\text { South Dakota } \\
\text { South Dakota . (1881) }\end{array}$ & & & 8 & & 16 & & 38 & & 70 & & 103 & & 135 & & 182 & 2 & 308 & 40 & 379 & \\
\hline $\begin{array}{l}\text { Tennessee } \\
\text { Tennessee } \\
\text { Vanderbilt }\end{array} \ldots . .(1794)$ & $\begin{array}{l}4 \\
7\end{array}$ & & $\begin{array}{l}16 \\
30\end{array}$ & 1 & $\begin{array}{l}29 \\
45\end{array}$ & 2 & $\begin{array}{l}41 \\
80\end{array}$ & 2 & $\begin{array}{l}112 \\
150\end{array}$ & & $\begin{array}{l}169 \\
374\end{array}$ & 9 & $\begin{array}{l}276 \\
567\end{array}$ & $\begin{array}{l}12 \\
36\end{array}$ & $\begin{array}{l}670 \\
809\end{array}$ & 37 & $\begin{array}{l}1122 \\
1301\end{array}$ & $\begin{array}{l}262 \\
189\end{array}$ & $\begin{array}{l}1229 \\
1301\end{array}$ & $\begin{array}{l}253 \\
207\end{array}$ \\
\hline $\begin{array}{l}\text { Texas } \\
\text { Houston }\end{array}$ & & & & & & & & & & & & & 72 & & 231 & 9 & 664 & 120 & 1192 & 192 \\
\hline $\begin{array}{l}\text { Rice .......... (1891) } \\
\text { Southern }\end{array}$ & & & & & & & & & 81 & 3 & 151 & 6 & 206 & 12 & 392 & 26 & 660 & 115 & $\begin{array}{r}1192 \\
875\end{array}$ & 88 \\
\hline $\begin{array}{c}\text { Methodist } \ldots(1910) \\
\text { Texas Tech } \ldots(1923)\end{array}$ & & & & & & & & & $\begin{array}{l}83 \\
16\end{array}$ & & $\begin{array}{r}112 \\
70\end{array}$ & & $\begin{array}{l}283 \\
100\end{array}$ & & $\begin{array}{l}531 \\
471\end{array}$ & 9 & & $\begin{array}{r}49 \\
102\end{array}$ & 955 & \\
\hline $\begin{array}{l}\text { Texas } \\
\text { Texas A \& M (1876) }\end{array}$ & & & $\begin{array}{r}45 \\
9\end{array}$ & & 72 & & 194 & & 422 & 19 & 639 & 46 & $\begin{array}{l}934 \\
175\end{array}$ & 86 & $\begin{array}{r}1424 \\
401\end{array}$ & 154 & $\begin{array}{r}2427 \\
716\end{array}$ & $\begin{array}{l}438 \\
215\end{array}$ & $\begin{array}{r}3726 \\
926\end{array}$ & $\begin{array}{l}454 \\
234\end{array}$ \\
\hline $\begin{array}{l}\text { Utah } \\
\text { Brigham Young }(1875) \\
\text { Utah ........ }\end{array}$ & & & 30 & & 31 & & 62 & & $\begin{array}{r}67 \\
102\end{array}$ & & $\begin{array}{l}117 \\
149\end{array}$ & & $\begin{array}{l}169 \\
250\end{array}$ & & $\begin{array}{l}330 \\
438\end{array}$ & 55 & 1178 & $\begin{array}{r}78 \\
242\end{array}$ & $\begin{array}{l}1267 \\
1520\end{array}$ & $\begin{array}{r}58 \\
245\end{array}$ \\
\hline $\begin{array}{l}\text { Vermont } \\
\text { Vermont } \ldots \ldots(1791)\end{array}$ & 20 & & 89 & & 80 & & 105 & & 128 & & 152 & & 200 & & 220 & & 579 & 24 & 563 & \\
\hline $\begin{array}{l}\text { Virginia } \\
\quad \text { Virginia } \\
\text { Virginia }\end{array}$ & 40 & & 50 & 2 & 70 & 4 & 120 & 4 & 172 & 16 & 338 & 26 & 592 & 36 & 1111 & 41 & 1699 & 223 & 2006 & 172 \\
\hline $\begin{array}{l}\text { Polytech. ... (1872) } \\
\text { Washington } \\
\text { Washington }\end{array}$ & 1 & & 4 & & 12 & & 30 & & 61 & & & & 135 & & 289 & & 626 & 154 & 877 & \\
\hline State ..... (1890) & & & 7 & & 23 & & 74 & & 200 & 2 & 406 & 2 & 600 & 17 & 750 & 41 & 853 & 142 & 1010 & 162 \\
\hline
\end{tabular}




\begin{tabular}{|c|c|c|c|c|c|c|c|c|c|c|c|c|c|c|c|c|c|c|c|}
\hline Washington .... (1861) & & 24 & & 41 & & 120 & 2 & 258 & 13 & 356 & 33 & 700 & 38 & 1104 & 113 & 1876 & 154 & 2187 & 386 \\
\hline $\begin{array}{l}\text { West Virginia } \\
\text { West Virginia . (1867) }\end{array}$ & 4 & 17 & & & & & & & & & 4 & 232 & 3 & 461 & & 684 & 101 & 814 & \\
\hline $\begin{array}{l}\text { Wisconsin } \\
\text { Marquette } \\
\text { Wisconsin }\end{array}$ & & 10 & & 18 & & 30 & & 53 & 2 & 93 & 4 & 172 & & 310 & & & 38 & 536 & \\
\hline $\begin{array}{l}\text { Madison } \ldots(1836) \\
\text { Milwaukee ... }\end{array}$ & 8 & 81 & 5 & $\begin{array}{r}151 \\
28\end{array}$ & 18 & $\begin{array}{r}276 \\
30\end{array}$ & 34 & $\begin{array}{r}422 \\
41\end{array}$ & 130 & $\begin{array}{r}485 \\
50\end{array}$ & 160 & $\begin{array}{r}777 \\
78\end{array}$ & 298 & $\begin{array}{r}1455 \\
149\end{array}$ & 397 & $\begin{array}{r}2417 \\
663\end{array}$ & $\begin{array}{r}913 \\
16\end{array}$ & $\begin{array}{r}2973 \\
938\end{array}$ & 819 \\
\hline $\begin{array}{l}\text { Wyoming } \\
\text { Wyoming }\end{array}$ & & 14 & & 28 & & 46 & & 75 & & 104 & & 154 & & 284 & 7 & 465 & 89 & & \\
\hline
\end{tabular}

Source: Figures in these tables were drawn from a variety of sources. They are, of course, based on differing counting techniques and are not necessarily compatible at all times. In cases of extreme variations we have omitted the information. The main sources on library collections were: Annual Report of the Commissioner of Education for 1876, 1900, and 1910; the Biennial Survey of Education for 1918-20, 1928-30 and 1938-40; the Library Statistics of Colleges and Universities: Institutional Dota for 1960-61 and 1970-71, and the Preliminary Report (December 1975) of the Survey of College and University Libraries of the National Center stitutional Data for 1960-61 a for Education (19) 20-1961 (Princeton University Library); the Academic Library Statistics 1970-71 and the ARL Statistics 1974-75, both issued by the Association of Research Librares, formation on the number of Ph.D. degrees come from the above quoted Annual Reports and Biennial Surveys; M. Irwin, American Universities and Colleges, 6.
(1952); Index to American Doctoral Dissertations 1960-61 and 1970-71 as well as from ARL Statistics 1974-75, accounting for the incomplete data for 1975.

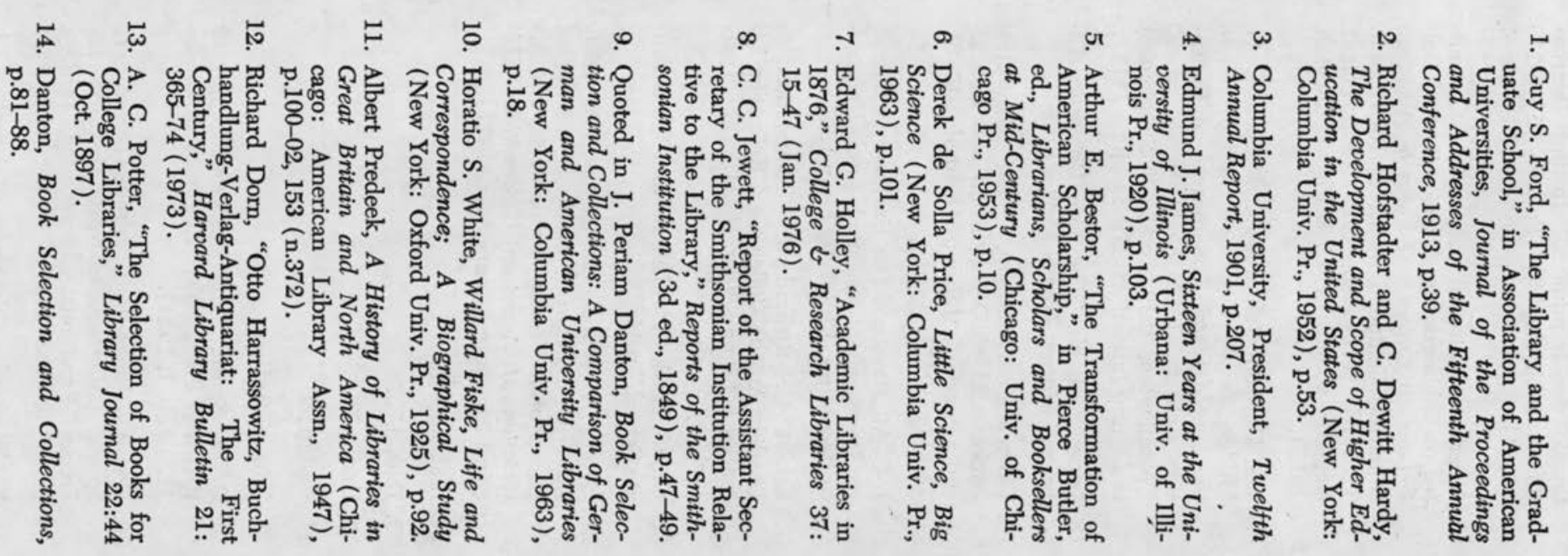


15. M. B. Iwinski, "La statistique internationale des imprimées," Institut International Bibliographie, Bulletin 16:1-139 (1911).

16. American Historical Association, Committee on Bibliography, A Union List of Collections on European History in American Libraries, Compiled by E. C. Richardson. Trial ed. (Princeton, 1912). Supplement. Copies Added, 1912-1915. (Princeton, 1915).

17. W. Dawson Johnston and Isadore G. Mudge, Special Collections in Libraries in the United States, U.S. Bureau of Education Bulletin, 1912, no.23, whole no.495 (Washington, 1912), p.85-88. Supplement in Library Journal 38:331-33 (June 1913).

18. James T. Babb, "The Yale University Library," Library Trends 15:208 (1966).

19. Lawrence Thompson, "The Historical Background of Departmental and Collegiate Libraries," Library Quarterly 12:4974 (Jan. 1942).

20. J. C. M. Hanson, "The University Library: Its Development and Problems," University Record n.s. 13:207-08 (July 1927).

21. Ernest C. Richardson, "Cooperation in Lending Among College and Reference Libraries," Library Journal 24:32-36 (July 1899).

22. Guy S. Ford, "The Library and the Graduate School," p.44.

23. George A. Works, College and University Library Problems: A Study of a Selected Group of Institutions Prepared for the Association of American Universities (Chicago: American Library Assn., 1927).

24. Ibid. p.14-15.

25. Ibid. p.75.

26. Ibid. p.76.

27. Ibid. p.39.

28. Ibid, p.40-41.

29. C. W. Smith, "The Vanishing Supply of Research Periodicals," Library Journal 49: 117 (Feb. 1, 1924).

30. Ernest C. Richardson, An Index Directory to Special Collections in North American Libraries (Provisional ed., unedited; Yardley, Pa.: F. S. Cook, 1927).

31. W. W. Bishop, "Resources of American Li- braries," Library Quarterly 8:445 (Oct. 1938).

32. Abraham Flexner, Universities; American, English, German (New York: Oxford Univ. Pr., 1930), p.79.

33. Princeton University Library, College and University Library Statistics; 1919/20 1943/44 (Princeton, 1947).

34. Bishop, "Resources of American Libraries," p.475.

35. See, for example, Wilhelm Munthe, American Librarianship from a European Angle. An Attempt at an Evaluation of Policies and Activities (Chicago: American Library Assn., 1939).

36. Dan Lacy, "War Measures, Past and Present," in Pierce Butler, ed., Librarians, Scholars and Booksellers at Mid-Century (Chicago: Univ. of Chicago Pr., 1953), p.89.

37. Reuben Peiss, "European Wartime Acquisitions and the Library of Congress Mission," Library Journal 71:863-76 (June 15, 1946).

38. Carol A. Nemeyer, Scholarly Reprint Publishing in the United States (New York: Bowker, 1972), p.50.

39. Robert B. Downs, "Wartime Co-operative Acquisitions," Library Quarterly 19:157-65 (July 1949).

40. Lacy, “War Measures,” p.89.

41. Edmond L. Applebaum, "Foreign Acquisitions Programs of the Library of Congress," in Theodore Samore, ed., Acquisition of Foreign Materials for U.S. Libraries (Metuchen, N.J.: Scarecrow, 1973), p.18-27.

42. Glenn F. Read, "SALALM: Thoughts on the Birth and Development of an Organization," in D. A. Clarke, ed., Acquisitions from the Third World (London: Mansell, 1975), p.177-91.

43. Library Resources for International Education, A Report Submitted by the Task Force on Library and Information Resources to the Government/Academic Interface Committee, International Education Project, American Council on Education (Washington, D.C.: American Council on Education, 1975).

44. Hendrik Edelman, "The Death of the Farmington Plan," Library Journal 98: 1251-53 (April 15, 1973). 
45. John Dessauer, "Library Acquisitions. A Look into the Future," Publishers Weekly 207:17-28 (June 16, 1975).

46. Unesco, Book Production 1937-1954 and Translations 1950-1954 (Paris: 1955), p.13.

47. Unesco, Statistical Yearbook, 1973, p.612.

48. From annual compilations in Publishers Weekly.

49. From unpublished statistics compiled by the Association of American University Presses.

50. Books for College Libraries; A Selected List of Approximately 53,400 Titles Based on the Initial Selection Made for the University of California's New Campuses Pro- gram (Chicago: American Library Assn., 1967). 2d ed. published in 1975.

51. Bernard Fry and Herbert S. White, Economics and Interaction of the PublisherLibrary Relationship in the Production and Use of Scholarly and Research Journals. Final Report (Washington, D.C.: National Science Foundation, Office of Science Information Services, 1975).

52. R. M. Hughes, A Study of the Graduate Schools of America; Read Before the Association of American Colleges, January 1925 (Oxford, Ohio: Miami Univ., 1925).

53. Albert R. Bowker, "Quality and Quantity in Higher Education," Journal of the American Statistical Association 40:1-15 (March 1965).

Hendrik Edelman is assistant director for collection development, and G. Marvin Tatum, Jr., is humanities librarian, Cornell University, Ithaca, New York. 